\title{
SB 933
}

. $\mathrm{H} 82$

Copy 1

\section{THE ECONOMIC STATUS OF INSECTS AS A CLASS.}

\author{
BY L. O. HOWARD.
}

Address of the Retiring President of the Biological Society of Washington, Delivered January 18, 1899.

[Reprinted from ScIENCE, N. S., Vol. IX., No. 216, Pages 233-247, February 17, 1899.] 


\section{$5 B 933$ .482}

\section{E3 ${ }^{1}$. of $D_{\text {. }}$}

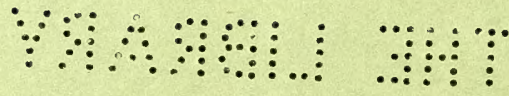

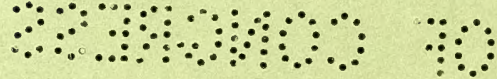




[Reprinted from ScIENCE, N. S., Vol. IX., No. 216, Pages 238-24\%, February 17, 1899.]

THE ECONOMIC STATUS OF INSECTS AS A CLASS.*

THE popular conception of insects in general is undoubtedly that they are injurious. Many writers, it is true, have pointed out the benefits derived from insects, but we think of their damage to crops and of their annoyance to man and animals, and this aspect of the subject is at once apt to preponderate in our minds. It is more than 80 years since Kirby and Spence contrasted the injuries caused by insects with the benefits derived from them, and it has not been comprehensively done since. In the meantime, whole groups of important injuries have been developed and whole classes of beneficial work have been discovered. Moreover, the tendency of modern thought has not taken this direction. The biologic taxonomic and phylogenetic, and other aspects of large groups of forms of life have been considered to the exclusion of the economic aspect, and even where this side has attracted attention investigators have confined themselves to specific problems and have not generalized. It may be interesting, therefore, once more to contrast the injurious insects with the beneficial ones in an effort to gain a clearer idea of the status of the group in its relations with man.

In a broad way, we may consider the subject under the following heads :

* Address of the retiring President of the Biological Society of Washington, delivered January 18, 1899. 
Insects are injurious :

1. As destroyers of crops and other val' uable plant life.

2. As destroyers of stored foods, dwellings, clothes, books, etc.

3. As injuring live stock and other useful animals.

4. As annoying man:

5. As carriers of disease.

Insects are beneficial :

1. As destroyers of injurious insects.

2. As destroyers of noxious plants.

3. As pollenizers of plants.

4. As scavengers.

5. As makers of soil.

6. As food (both for man and for poultry, song birds and food fishes) and as clothing, and as used in the arts.

DESTROYERS OF CROPS AND OTHER USEFUL PLANTS.

In the present balance of nature one of the chief functions of insect life is to keep down superabundant vegetation. Almost every kind of plant has its insect enemies, and has had such enemies for many thousands of years. So soon as man began to. make an effort to upset nature's balance by cultivating certain plants at the expense of others he encountered nature's opposition by means of the increase of insect enemies of the particular plant enltivated, and almost as early as there is any record of agriculture in literature there is also mention of the destruction to crops caused by insects. Witness the writings of the prophet Joel, who might almost be termed an agricultural pessimist.

At the present time almost every culti. vated crop has not only its thousands upon 
thousands of individual insect enemies, but it is affected by scores and even hundreds of species. A mere tabulation of the insect enemies of the apple already recognized in this country shows 281 species, of clover 82 species, and of so new a crop as the sugar beet 70 species. The insects of the vine, of the orange, of the wheat crop, and, in fact, of all of our prominent staples, show equally startling figures.

The actual damage which is done by insects in this way is difficult to express. Many attempts have been made by writers on economic entomology to express it in money values. For example, it was estimated by the late Professor Riley that the average annual damage to cultivated crops by injurious insects in the United States amounted to three hundred millions of dollars. The loss from the ravages of one species alone, the chinch bug, during one year was estimated at sixty millions of dollars. While it is true that the combined losses of individual growers might reach such enormous sums as these, there is an element in the total loss which we must not fail to take into consideration, and that is the enhanced value of the portion of the crop which remains. Even in the case of an individual a man may lose, for example, half of his crop through the work of the chinch bug, and yet, through widespread damage by this insect, the money value of the portion harvested may reach an amount almost as great as would have been gained through the low prices of a successful year of no insect damage As this applies to an individual, it applies much more strongly to a State or to the country at large, so that even in the year when the grain crop of 
the country was said to have been damaged to the extent of sixty millions of dollars it is safe to say that the total price gained for the crop was as great as it would otherwise have been. These estimates of damage, therefore, would much better be ex. pressed in terms of bushels, or some other measure, than in money value.

It is this aspect of our subject, the damage done by injurious insects to agrieulture, that has given rise to the comparatively new branch of applied science which we now know as economic entomology, and which, although originating in Europe, has been encouraged to such an extent in our own country, owing partly to our greater necessities and partly to our practical turn of mind, that it is safe to say that at present A merica leads the rest of the world in this direction.

It is undoubtedly true that this enormous injury to crops is the chief item in a general consideration of the injuries brought about by insects.

AS DESTROYERS OF STORED FOODS, DWELLING, CLOTHES, BOOKS, ETC.

It is safe to say that there is bardly any product of man's ingenuity, hardly one of the thousands of useful materials upon which depend his comfort and happiness, which is not damaged, directly or indirectly, by insects. The timbers of which his dwellings are built, nearly all of his household utensils, his garments, practically everything which he uses as food, many of the liquids used as drink, his books, the ornaments with which he surrounds himself, the medicines which he takes when sick, the very tobacco with which he solaces him- 
self-all are destroyed or injurionsly affected by insects. There is, perhaps, one group of exceptions, and that is those articles which are composed wholly of metal, and yet even here insects may occasionally play an injurious part, since instances are on record of the destruction of lead pipes by insect larvæ, and the perforation of the metal linings of water tanks by small beetles.

Such injuries to human products are more frequent and serious in tropical regions than in temperate zones, but even here insects of this nature cause very serious inconven. ience and great annual loss. It will answer our purpose, perhaps, to list some of the varying substances which are damaged in this way, to get an idea of their almost uni. versal character: Ham, cheese, salted fish, butter, lard, dried mushrooms, rye bread, sweetmeats and preserves, powdered coffee, almonds and other nuts, raisins, breakfast foods, chocolate, ginger, rhubarb, black pepper, vinegar, sugar, wines, canned soups, tobacco, snuff, licorice, peppermint, aromatic cardamon, aniseed, aconite, belladonna, musk, opium, ginseng, chamomile, boneset, hides, shoes, gloves and other leather articles, furniture, carpets, drawings and paintings, paint brushes, gun wads, combs, etc., made of horn; hay, oats, straw, willow baskets, ax handles, ladders, wheel spokes and all sorts of agriculural implements with wooden handles, barrels, wine casks, corks of wine bottles, sheets of cork, natural history collections, including skeletons and mummies, and even Persian insect powder! The mention of this well-known insecticide reminds one of the latest discovery, which is that certain flies in California 
breed in the erude petroleum pools in the vicinity of oil wells, a fact which is almost paradoxical in view of the extensive use of petroleum as an insecticide.

AS INJURIOUS TO LIVE STOCK AND OTHER: USEFUL ANIMALS.

Every species of animal which has become domesticated and is of value to man. possesses its insect parasites and enemies. These in many cases are the same species. which affect man and which we will mention in the next section; others are specific to the animals or groups of animals which they affect. Horses, cattle, sheep, all possess insect enemies which are not only very deleterious to their health, but frequently cause their death in numbers.

The disgusting bot fly of the horse, whose maggots live in incredible numbers in the stomach and intestines of this noble friend of the human race; the bot fly of the ox, which causes innumerable sores on the backs of cattle and by its perforations ruins their hides for commercial use; the bot fly of the sheep, which inhabits the nasal and orbital sinuses of the sheep and produces insanity and death-will instantly be recalled by those who are familiar with stock raising, while hundreds of other species, some in no less degree, as the horn fly, the numerous gad flies, including the Tsetse fly of A frica, the serew worm fly of our South. western country, unite to make the lives of domestic animals a burden to themselves and a trial and a loss to their owners.

An interesting attempt was made some years ago by a prominent Western agricultural newspaper, The Farmers' Review, to estimate approximately the pecuniary loss 
Hom the attacks of a single one of these insects-the ox bot fly, or ox warble-on the cattle received at the Union Stock Yards, of Chicago. It was estimated that 50 per cent. of the cattle received each year stre affected. The number of cattle received at the yards during six months of the year 1889 was $1,335,026$; the average value of the hide was $\$ 3.90$; the usual deduction for hides damaged by the ox warble was onethird. Estimating at less than one-third, say $\$ 1.00$, the actual loss during six months on hides alone was $\$ 667,513$. When to this was added the loss for depreciation in value and lessened quantity of beef, the loss for each infested animal was put at $\$ 5.00$, $x$ very low estimate, indicating the total loss from the animals in the Union Stock Yards, of Chictgo, for a period of six months of $\$ 3,336,565$.

\section{AS ANNOYING MAN.}

There are very few regions of the habit. able globe where man is not personally subject to more or less annoyance by insects. In this part of the world we naturally think at once of mosquitoes, house flies, fleas, and of a certain other species which it will not be necessary to name.

A susceptible individual some years ago wrote to the Department of Agriculture and said that he had come over from the old country and settled in New Jersey, but that the mosquitoes bothered him so greatly that on the advice of friends he moved to northerm New York. Here he found that during a certain portion of the year black flies made life unendurable; thereupon he packed his household effects and moved to North Carolina. Here, however, in the 
summer months red bugs, or jiggers, bothered him to such an extent that he feared he would go crazy, and in this desperate condition he applied to this office to learn whether there existed in the United States a locality where a sensitive individual could find peace from attacks of insects. He said that he had been told that in the Wester. country the buffalo gnat was greatly to be feared, while certain other biting flies would be sure to keep him in a constant state of dermal irritation; that further south he knew that peaceful nights were to be gained in the summer time only under the protection of mosquito bars. He had thought of the newly developing country of Alaska, but had recently seen an account in the nowspaper of the ferocity of the Alaskan mosquitoes, which bad practically destroyed his last hope.

Accustomed as most of us are to the mosquitoes of temperate North America, we hardly realize the impression which they made upon the early English travellers. A story told by Kirby and Spence, to the effect that Mr. Weld in his travels relates from General Washington that in one place the mosquitoes were so powerful as to pieree whrough his boots, has always excited my interest and curiosity, and I recently took the trouble to consult the original publication, which is 'Isaac Weld's Travels through North America, 1795-1797,' London, 1799. In speaking of Skenesborough, in northern New York, Mr. Weld dilates upon the number and ferocity of the mosquitoes, and makes use of the following words: "Gen. eral IVashington told me that he never was so much annoyed by mosquitoes in any part of America as in Skenesborough, for 
that they used to bite through the thickest boot." Now, knowing that the boots of those days were very thick and that the mosquitoes of that time must have been structurally identical with those of to-day, there arises instantly a question of veracity between Mr. Weld and General Washington; and as we know from Dr. Weems' veracious history that General Washington was so constituted that he could not tell a lie, it looks very much as though Mr. Weld, like many another English traveller who has written a book on his return home, has been inclined to overstate the truth.

In these days of comparative persomal cleanliness some of the most disgusting of the insect annoyers of man have dropped out of sight. The lice, which in former days were common in all classes of society, from king to peasant, are now comparatively unknown. The itch disease, which carried off many a famous character in history, is equally rare. That it still persists, however, is shown by an occasional case reported in medical journals. For example, Dr. Robert Hessler, of Indianapolis, reported in 1892 a case in his own practice of typical Norway itch in which the itch mites were present in the slin of the patient in enormous numbers. A rough estimate showed seven million eggs and two million mites.

Those of us who live in a reasonably civilized way are confined, in our experience of annoying insects, largely to the forms mentioned in our opening paragraph, namely, mosquitoes and house flies and rarely fleas; but a glance through the medical literature reveals the existence of more or less frequent cases of such a nature that they are 
little less than horrible. Prominent among. these are the cases of so called Myasis, and especially those resulting from the attacks of the screw worm fly, Compsomyia macelTarice.

Residents of temperate regions are fortunate as compared with those of tropical regions in respect to the personally annoying insects. Our troubles from these individually insignificant causes are intensified to a degree in warmer countries, where the comfort of the individual absolutely depends upon the adoption of measures, always difficult and frequently impracticable, to exclucle insects from his person and from his food. This is so well known in these days of numerous books of travel that I will close this aspect of our question simply with a guotation from a poet of the Indies, written many years ago:

"On every dish the booming beetie falls,

The cockroach plays, or caterpillar crawls :

A thousand shapes of variegated hues

l'arade the table and inspect the stervs.

To living walls the swarming hundreds stick,

Or court, a dainty meal, the oily wick;

Heaps over heaps their slimy bodies drench,

Ont go the lamps with suffocating stench.

When hideous insects every plate defile,

The laugh how empty, and how forced the smile!"

\section{AS CARRIERS OF DISEASE.}

Manson's demonstrated transmission of the filaria diseases of the East (elephantiasis, ehyluria and lymph scrotum) by insects; the discovery by Salmon and Smith of thes carriage of the germ of Texas fever by the well known Southern cattle tick; the discovery by Koch of the fact that the Tsetse fly of Africa is so destructive to animals, not by its bite alone, but by carry- 
ing into the circulation of the animai that it attacks the micro-organisms of disease; the demonstration by Howe and others of the previously suspected fact that the purulent conjunctivitis of the Egyptians is spread by the house fly; the partly proven hypothesis of Manson and Grassi of the relation existing between mosquitoes and malaria; the circumstantially proven carriage of the germs of Asiatic eholera and typhoid fever by flies; the demonstration claimed by Finlay of the carriage of a mild type of yellow fever by mosquitoes; the suggestion by Hubbard that the 'pink eye' of the South is spread by Hippelates; the wellrecognized fact among the Europeans of the Fiji Islands that without a veil a serious native eye disease will spread through the medium of gnats; the suggestion by Symond of the agency of fleas in the spread of the bubonic plague; the demonstration of anthrax bacilli in maliguant pustules in human beings, caused by the bite of Tabavus and Stomoxys-all indicate an important and very injurious function of insects practically unsuspected until comparatively recent years. It is, in fact, a rapidly increasing field of investigations, the possibilities of which cannot be accurately established at the present time. It is, however, not a field which should be left entirely to the medical bacteriologist; the entomologist should have a share. The life histories and habits of the insects concerned in the damage should be thoroughly understood, since it is not impossible that otherwise the medical investigators may find themselves arriving at perhaps unwarranted conclusious. For example, it is a fact probably unknown to the medical men who may be 
strongly impressed by the suggested carriage of typhoid germs by flies, that the house fly, so common in our dining rooms, does not breed in and rarely visits human excrement, while those other kinds of flies, which do so breed, are rarely attracted to articles of food used by human beings. In the crowded and ummatural conditions of army camps, however, and especially where cavalry regiments are stationed, so that there are great amounts of horse manure, the house fly may breed in such enormous numbers as to render of very likely occur. rence a departure from the normal food habits of the adult.

Enough has been shown, however, to emphasize the potentiality of this phase of insect injury.

\section{BENEFITS}

AS DIESTROYERS OF INJURIOUS INSECTS,

The economic bearings of insect enemies of insects are very great, and perhaps this is, all things considered, the most important of the beneficial function of insects as a class.

In the eternal warfare of organism upon organism, in the perpetual strife of species, one preying upon another and that upon a third, the complications of relations of forms which determine the abundance of one species and the scarcity of another are nowhere more marked than among the insects. In fact, to the student of insects who has followed out even a single chain of these inter'relationships the thought must necessarily come that upon its organic environment, and especially upon its relations with its living neighbors of the animal kingajom, depend the chances of a species not only for 
increase, but for survival almost to no lesser degree than upon its inorganic environment. Temperature is the great factor which controls the geographical distribution of life, and temperature is at the back of all these apparent living first causes which control the abundance of a species in a given region, provided we trace them far enough. Yet these living causes, themselves affected by other living causes in an almost endless chain, sometimes, to all appearance, dwarf even temperature as a controlling factor.

There is not a species of insect that has not its natural enemies in the guise of other insects; there is not one of these other insects which has not its own insect foes. From a single species of Bombycid moth, the larva of which frequently damage forests in Europe to an alarming extent, there have been reared no less than sixty species of hymenopterous parasites. From a single caterpillar of Plusia brassica have been reared 2,528 individuals of a little hymenopterous parasite, Copidosoma truncatellum.*

Outbreaks of injurious insects are frequently stopped as thongh by magic by the work of insect enemies of the species. Hubbard found, in 1880, that a minute parasite, Trichogramma pretiosa, alone and unaided, almost annihilated the fifth brood of the cotton worm in Florida, fully ninety per cent. of the eggs of this prolific erop enemy being infested by the parasite. Not longer ago than 1895, in the city of Wash-

* This observation, which for some years 'held the record,' as the expression is, was made by Mr. Pergande, of the U. S. Department of Agriculture. Re. cently, however, Professor A. Giard, of Paris, has more than 3,000 specimens of the same parasite reared from a Plusia caterpillar. 
ington, more than ninety-seven per cent. of the caterpillars of one of our most important shade-tree pests were destroyed by parasitic insects, to the complete relief of the city the following year. The Hessian fly, that destructive enemy to wheat erops in the United States, is practicaily unconsidered by the wheat growers of certain States, for the reason that whenever its numbers begin to be injuriously great its parasites increase to such a degree as to prevent appreciable damage.

The control of a plant-feeding insect by its insect enemies is an extremely complicated matter, since, as we have already hinted, the parasites of the parasites play an important part. The undue multiplication of a vegetable feeder is followed by the undue multiplication of parasites, and their increase is followed by the increase of hyperparasites. Following the very instanee of the multiplication of the shadetree caterpillar just mentioned, the writer was able to determine this parasitic chain during the next season down to quatermary parasitism. Beyond this point, true intermal parasitism probably did not exist, but even these quaternary parasites were subject to bacterial or fungus disetse and to the attacks of predatory insects.

The prime cause of the abundance or scarcity of a leaf-feeding species is, therefore, obscure, since it is hindered by an abundance of primary parasites, favored by an abundance of secondary parasites (since these will destroy the primary parasites), hindered again by an abundance of tertiary parasites, and favored again by an abundance of quaternary parasites.

The subject of practical handling of in- 
sect enemies of insects has come into great prominence during the past ten years. The suggestion by the Rev. Dr. Bethune, of Canada, many years ago, of the desirability of importing the European parasite of the wheat midge into America was probably the first published international suggestion of this nature, and, although some subsequent correspondence between English and American entomologists ensued, no parasites were actually sent over. Later, attempts were made by LeBaron in the case of a parasite of the oyster-sbell bark-lonse of the apple, and by Professor Riley in the case of a parasite of the plum curculio, to transport parasites from one section of the United States to another, both attempts meeting with some slight success.

In 1873 Planchon and Riley introduced an American predatory mite, which feeds in this country on the grape vine Phylloxera, into France, where it became established, but where it accomplished no appreciable results in the way of checking the spread of this famous vine pest.

In 1874 efforts were made to send certain parasites of plant-lice from England to New Zealand, without recorded results of value.

In 1880 , in an article upon the parasites of American scale insects, the writer showed that internatioual transportation is especially easy, and especially deciruble in the case of these insects.

In 1883 Dr. Riley succeeded in importing a common European parasite of the imported cabbage worm into this country, where it established itself and has since proved to be a valuable addition to our fauna.

In 1891 the same distinguisher entomologist brought about the importation of one 
of the European parasites of the Hessian fly through the assistance of Mr. Fred. Enock, of London. This parasite maintained itself in this country certainly as late as 1895, but has accomplished no appreciable good, so far as has been ascertained, in limiting the increase of this destructive enemy to wheat.

All previous experiments of this nature were dwarferl into insignificance by the astounding success of the importation of Novius (Tedalia) cardinalis, a ladybird beetle, from Australia into California in 1889. This importation was made, as will be remembered, by Mr. Albert Koebele, an attaché of the Division of Entomology of the United States Department of Agriculture, whose expenses, however, were paid out of a fund appropriated to the Department of State, for the purpose of securing a representation from this country at the Melbourne Exposition. A California man, the late Mr. Frank McCoppin, happened to be at the lead of the Exposition Commission ; and, while the Jate Dr. C. V. Riley was endeav. oring in Washiugton to induce the Department of State to set aside a sum, from the Exposition fund, for the expenses of $\mathrm{Mr}$. Koebele, representatives of the State Board of Horticulture of California were pressing the same facts upon Mr. McCoppin, the head of the Commission. These efforts were being made independently and without consultation, hence it happened that after Mr. Koobele had succeeded in sending live Vedalias to California, and after these insects, by their rapid multiplication and voracious habits, had absolutely destroyed the cottony cushion scale in the orange groves of the State, a result which prac- 
tically saved millions of dollar's to California, and which attracted the attention of everyone interested in science or agriculture, a most unfortunate controversy en. sned between Dr. Riley and the California State Board of Horticulture as to the placing of the credit of carrying out this wonderfully successful experiment. This controversy embittered the last days of both Dr. Riley and Mr. McCoppin, and was the cause of a disturbance of the formerly pleasant relations between the United States Depart. ment of Agriculture and the State Board of Horticulture of California, which has only recently been overcome.

Following this successful experiment, the same insect, Novius cardinalis, was sent to South Africa, where it exterminated the white or fluted scale in that colony. The next year it was sent to Egypt, where it exterminated a congeneric scale insect in the gardens of Alexandria.

The following year Mr. Koebele, still an agent of the United States Department of Agriculture, was sent with the consent of the Honorable Jeremiah Rusk, but at the expense of the California State Board of Horticulture, to Australia, New Zealand and the Fiji Islands, for the purpose of securing other valuable beneficial insects for importation into California. Thousands of such insects, comprising a number of different species, nearly all, however, of them Coccinellids, or ladybirds, were sent over and established in California. Several of these species are still living in different parts of the State. The overwhelming success of the importation of Novius cardinalis was not repeated, but one of the insects brought over at that time, namely, Rhizobius 
ventralis, has unquestionably ridden many nlive groves of the destructive black scale, and is to-day present in many other orchards in such numbers that the scale practically makes no headway.

After this second Oriental trip the relations between the Department of Agricul. ture and the State Board of Horticulture of California became so strained that the California agents of the Department were given their choice by the Honorable Secretary of Agriculture to resign their positions or be transferred to Washington. Mr. Koebele resigned and was soon after employed by the then newly established Hawaiian Republic for the purpose of travelling in different countries and collecting beneficial insects to be introduced into Hawaii for the purpose of destroying injurious insects. It is difficult at this time to ascertain the exact results of the more recent portion of this work. Mr. Koebele's own published reports have dealt less with results than with the details of the introduction of insects, and anonymous newspaper reports are not to be accepted as scientific evidence. Fortumately, however, one of the collectors of the British Association for the Advancement of Science, Mr. R. E. C. Perkins, was in Hawaii during 1896 and made a report on Mr. Knebele's work to the committee ap pointed by the Royal Society and the British Association for investigating the fauna of the Sandwich Islands, which was published in Nature for March 25, 1897 . From this report it appears that the introduction of Coccinella repanda from Ceylon, Australia and China was so successful in the extermination of plant-lice upon sugar cane and other crops as to obviate all necessity for 
spraying. The introduction of Cryptolumus montrouzieri from Australia resulted in the entire recovery of the coffee plants and other trees which were on the point of being totally destroyed by the scale insect known as Pulvinaria psidii. Eight other introduced species had at the date of writing (November, 1896) been entirely naturalized and were reported as doing good work against certain scale insects. A Chal. cis fly, Chalcis obscurata, introduced from China and Japan, multiplied enormously at the expense of an injurious caterpillar which had severely attacked banana and palm trees. Mr. Koebele, when visiting Washington during November, 1898, mentioned a number of other importations of beneficial insects into Hawaii, about which it is as yet too early to speak.

A very recent instance of an interuational importation of striking value is the sending of Novius cardinalis from this country to Portugal, where the white or fluted scale has been checked and in many orchards exterminated in the course of a single year. This importation was made by the writer with the invaluable assistance of the California State Board of Horticulture.

Other experiments in this line are under way. A parasite of certain wax scales, which are abundant and injurious in the South, has been imported by the writer from Italy, with the cooperation of Professor Antonio Berlese, of the Royal Scuola di Agricoltura di Portici; while an effort is being made to bring from Europe insects which will prey upon the Gipsy moth which has been so great a plague about Boston; and other parasites of injurious scale insects in foreign countries are being studied with 
the purpose of eventually obtaining their introduction into the United States.

AS DESTROYERS OF NOXIOUS PLANTS.

Just as we have shown how important is the rôle played by insects in the destruction of cultivated and nseful plants, it will be easy to indicate their importance as destroyers of weeds and other noxious plants. We need only mention the common and cosmopolitan thistle butterfly (Pyrameis cardui), the equally common milkweed butterfly (Anosia plexippus), the purslane caterpillar (Copidryas gloveri), the burdock beetle (Gastroidea cyanea), and the purslane sphinx moth (Deilephila lineata) to recall to the mind of the experienced entomologist many other species which do similar work. They are here, as in the former case, perhaps the principal agents in preventing the undue increase of any one species of plant, but as we find here not an effort of man to combat Nature, as it were, by increasing the growth and spread of one species at the expense of the others, but the exact opposite, so, here also, to a degree we find Nature arrayed against man, and insects thus play by no means the same part in the destruction of weeds that they do in the destruction of cultivated crops. Nevertheless, they have an important function in this direction, and it is safe to say that the benefit which the agriculturist derives from their work in this way is very great. As long ago as the beginning of the century it was pointed out by Sparrman that a region in Africa, which had been choked up by shrubs, perennial plants and hard, half-withered and unpalatable grasses, after being made bare by a visitation of destructive grasshoppers, soon 
appeared in a far more beautiful dress, clothed with new herbs, superb lilies and fresh annual grasses, affording delicious herbage for the wild cattle and game.

In a similar way Riley has called attention to the fact that after the great grasshopper invasions of Colorado and other Westerm States in the years 1874 to 1876 there were wouderful changes in the character of the vegetation, the grasshopper devastations being followed by a great prevalence of plants which in ordinary seasons wer' scarcely noticed. It is true that some of these plants were dangerous weeds, but others were most valuable as forage for the half-starved live stock. Moreover, other plauts, and especially short or recumbent grasses, took on a new habit and grew luxuriantly; one species, for example, Eragrostis poceoides, ordinarily recumbent and scarcely noted, grew in profusion to a height of three and a-half feet.

An important, but not generally realized, benefit which is derived from the insects may be mentioned under this head, though not strictly belonging here. Kirby showed, 75 years ago, that the insects that attacked the roots of grasses, such as wireworms, white grubs, etc., in ordinary seasons only devour so much as is necessary to make room for fresh shoots and the product of new herbage, in this manner maintaining a constant succession of young plants and causing an annual though partial renovation of our meadows and pastures, "so that, when in moderate numbers, these insects do no more harm to the grass than would tho sharp-toothed harrows which it has sometimes been obliged to apply to hidebound pastures, and the beneficial operation 
of which in loosening the subsoil these insect borers closely imitate."

AS POLLENIZERS OF PLANTS.

It can no longer be doubted that cross fertilization is one of the very most important elements in the progressive development and continued health of the great majority of flowering plants, and, indeed, that it is with some almost a condition of existence. Opposition to this view, at no time especially strong since the publication of Darwin's great work, has become feebler and more feeble until at the present it is not worth considering.

Comparative experimentation with selffertilizing and cross-fertilizing plants, repeated with many species and genera, have shown a superior growth and vitality on the part of those subjected to cross-fertilization of such a degree as to leave not a semblance of a doubt; while in individual cases self fertilization has been scientifically shown to even result in a deterioration so marked that it has been compared to poisoning.

In this condition of affairs it at once becomes evident that the good oflices of insects in this direction are of incalculable importance, since it must be plain that of the natural agencies by which cross-fertilization of plants is accomplished insects are far and away the most prominent. Every investigation which has been undertaken of recent years, and activity in this field is increasing by leaps and bounds, has shown the most marvelous adaptations between the structure of flowers and the structure of their insect visitants, all in the line of facilitating or really enforcing the collect- 
ing and carriage of pollen by flower-visiting insects from one plant to another. An estimate of the numbers of the species of insects engaged in this work would include the forms belonging to whole families and almost orders, and if we could imagine the race of flower-visiting insects wiped out of existence the disastrous effect upon plant growth would be beyond estimate. I am not prepared to state that insects benefit plants in this way to such an extent as to overcome the results of the work of the plant-destroying species, but if it were possible to compare in any way the results of these two classes of work it is safe to say that the effect would be surprising.

We must, therefore, without going further into detail, place this pollenization of plants as one of the very most important beneficial functions of insects in their relatious to man.

\section{AS SCAYENGERS.}

Another beneficial function of insects, the importance of which can hardly be overestimated, is their value to humanity in doing away with, and rendering immocuous, dead matter of both plant and animal origin. This subject has never been discussed without reference to the famous statement by Linnaus that the offspring of three blowflies would destroy the carcass of a horse as quickly as would a lion; and while the exact statement in its details is open to doubt, still it serves to illustrate, in a striking way, the good offices of insects, and it is certainly true that after the offspring of the blow-fly have finished with the horse's carcass this would be left in a much less offensive condition than after the departure of the lion. 
There are inhabited regions in which the climate is so dry that dead bodies of animals never become offensive, but, by natural mummification, remain simply as cumberers of the earth. In such regions insects play little part. Wherever, however, there is sufficient moisture to produce a natural decay, there insects occur in swarms and hasten the destruction of the decomposing mass in a marked degree. Were the bodies of dead animals not destroyed by insects in this way, and, still more, were the destruction of dead vegetation not hastened as it is by the attacks of countless insects, it is perfectly easy to see that the earth would not be inhabitable, its surface would be covered with the indestructible remains of what was once life in some form.

Large groups of insects, comprising many thousands of species, take part in this in estimable work, and it will probably be unnecessary in order to bring about a realization of this value to dwell further upon the subject.

\section{AS MIAKERS OF SOIL,}

It is a. fact not generally realized that inseets must take an important part in the changes in the character of the soil which are constantly going on. Occurring in such countless millions, as they do, constantly penetrating the soil in all directious, frequently dragging vegetation below the surface and bringing the subsoil up to the surface, changing the character of the soil humus by passing it through their bodies, and fertilizing the earth by their own death and, decay, it is probable that insects are responsible for even more soil change than are the earth worms, which Darwin has placed before us in such an important light. 
Insects are found beneath the ground in incredible numbers; some of them pass their whole life underground, feeding upon roots and rootlets, upon dead and decaying vegetable matter, upon soil humus and upon other insects; many of them have their nests underground, although they get their food elsewhere; while others hide their eggs or pupæ underground.

The depth to which they penetrate is something surprising; the minute insects of the family Podurida have been found swarming literally by the million at a depth of six to eight feet in a stiff clay subsoil.

AS FOOD AND CLOTHING AND AS USED IN THE ARTS.

In this rôle insects play an important part. Insects as food, and their products as clothing, are well known to all. The great silk industry of the world is derived wholly from insects, and almost entirely from a single species, the silkworm of commerce.

As food, insects have formed articles of diet for certain savage peoples since the beginning of the human race. Hope, in 1842, catalogued forty-six species of insects used as food, and Wallace, in 1854, showed that insects of six different Orders were used as food by the Indians of the Amazon. Semi-civilized peoples to-day use certain insects as food, as witness the consumption of Corixa eggs by the Mexicans, and a book has been written under the caption "Why not eat insects?' for the purpose of showing that many possibilities in the way of dieteties are being ignored to day. M. de Fontvielle, in addressing the Société d'In. sectologie, in 1883, expressed regret that the 
attempts made to popularize the use of insects as food have made so little progress, and said that we ought not to forget the remark of the Roman Emperor who said that the body of an enemy never tasted bad, and that the banquet of the Society would always lack something so long as there was not placed before them at least some grasshopper farina and fried white worms.

A single insect, the honey bee, furnishes a notable article of food, and is the basis of a great and world.wide industry.

As food for poultry, song birds and food fish, insects are indirectly of great benefit to man. Not only do they provide living food for such animals, but Corixa mercenaria, a water bug, is now being imported by the ton from Mexico into England as food for birds, poultry, game and 6sh. One ton of these bugs has been computed by Mr. G. W. Kirkaldy to contain $250,000,000$ of insects (Entomologists' MIonthly Magazine, August, 1898).

Iu the days of pure empiricism in medicine, insects were used extensively, and we have only to mention the Spanish fly to show that they are still of some value.

In the arts, shellac and Chinese white wax, as is well known, are insect products, as also are the formerly greatly used cochineal dye and Polish berry dye, the so-called berry in this case being an insect and not a ber'ry.

The last-named instances are all derived from scale insects, a group of astonishing capacity for multiplication, the commercial possibilities of which are by no means exhausted, as I took pleasure in showing in a paper read before the American Association 
tor the Advancement of Science in 1897. It should be noted here, also, that there is good reason to believe that the manna of the Bible, upon which the Children of Israel subsisted while in the IVilderness, was also the secretion of a scale insect.

SUMMARY OF THE HABITS OF INSECTS.

After this general account, arranged under the classes of damage and classes of benefits brought about by insects, it will be well to attempt an arrangement of the subject in a somewhat different manner, in order to gain, if possible, some light as to the relative proportion of insects which are injurious or beneficial.

It will be manifestly impossible to catalogue the species or the genera in this way, and it will be obvious that a classification from families will be lacking in exactness, since some of the families are very large in number of species and others exceedingly small; but, taking the groups as a whole, no better and speedier means suggests itself than to summarize the habits by families.

Another difficulty, however, which arises in such a classification is the fact that some orders are in a much more advanced stage of classification than others, and the force which is given to a family as a taxonomic group varies with the views of the latest monographer. Nevertheless, taking only the older and generally accepted families and analyzing habits, we find the situation to be as follows:

Of 33 families of Hymenoptera, but two are strictly plant-feeding; the Cynipidx, or gall flies, are in the main injurious to plauts, but some forms are parasitic; nine families are strictly parasitic upon other 
insects; fifteen are predatory upon other insects; two, comprising the bees, bave no other especial vaiue in their relations with man than as pollenizers of plants, or producers of honey ; three, comprising the ants, are beneficial as scavengers, but injurious in their other relations. It must be remembered, however, that at least 27 of the 33 families are of the greatest value in the cross-fertilization of plants, in which work the insects of this order perhaps take the lead.

In the Coleoptera, or beetles, considering 82 families, the insects of nine families on the whole are injurious, and of 23 families on the whole are beneficial as destroying injurious insects; 10 families are beneficial as scavengers, and 30 , or more, mostly small groups of little importance, contain some scavengers and many neutral forms of practically no economic importance, although certain of them visit flowers; two families contain both injurious and beneficial forms, as well as many that are neutral.

In the Siphonaptera, or fleas, the species of the single family are parasitic upon warm-blooded animals.

In the Diptera, or true flies, if we classify the families according to habits of the majority of the species in each, we get approximately : injurious families, 10 ; predaceous families, 11 ; parasitic family, 1 ; scav. engers, 19. In point of numbers, of individuals in this order, as well as in the Coleoptera, no doubt the injurious will exceed the predaceous; while in the Diptera the scavengers will probably equal all of the others put together.

In the Lepidoptera practically all of the 60 odd families are injurious through the 
damage done by their larvi to vegetation, but here again it must be remembered-and the same comment holds for many of the Diptera which we have just cousidered - that the adult insects are among the most active and frequent visitors of flowers and have a great and beneficial effect on cross-fertilization.

In the Trichoptera the insects of the single family feed upon aquatic plants and have no economic value except as furnishing food for food fishes.

The insects of the single family in the order Mecoptera are indifferent in their economic relations, though probably slightly beneficial.

In the Neuroptera all of the seven families are beneficial through their predaceous habits, with the exception of the Sialidx, which, since their larva are aquatic, may be termed indifferent or neutral, though it has both a beneficial and an injurious rela. tion to food fishes.

In the Homoptera we have nine families, all of which are injurious except that here and there a species has had a commercial value, like the lac and dye insects.

In the Heteroptera there are 11 families which are strictly plant feeders; 8 are strictly predaceous; 3 are both injurious and predaceous; while the economic value of 13 is more or less doubtful. Most of these last are aquatic and have some value as fish food.

The insects of the single family of the order Physaptera are injurious.

In the Orthoptera we have one family of strictly predaceous habits; one which has a mixed food and is partly injurious and partly beneficial as its species become scav- 
engers; the habits of 1 family are unknown; while in the 4 remaining families the species are all injurious as destroyers of vegetation.

The insects of the single family of the order Euplexoptera are probably beneficial as predatory forms and scavengers.

The single family of the order Mallophaga is injurious, containing parasites $\mathrm{O}$ hirds and mammals.

In the Corrodentia the habits of the insects of the single family are on the whole of little economic importance, though the species are to be classified in the main as scavengers.

In the Isoptera the forms belonging to the two families are injurious.

In the Order Plecoptera the species of the single family are practically neutral in their economic relations, although they possess some value as fish food.

All of the insects of the single family of the order Odonatia may be called beneficial; the adults are predaceous upon other insects and are thus strictly beneficial, but the larvæ may in a sense be termed injurious, since they are aquatic and prey upon other aquatic insects which themselves may be food for fishes.

The insects of the single family of the order Ephemerida are of little economic value, except that they are important fish food.

Lastly, the insects of eight of the families of 'Thysanura are beneficial as scavengers and soil markers, while some of the species of one family are somewhat harmful from the damage which they do in households.

Tabulating the facts thus gained we have the following: 
Injurious as feeding upon cultivated and useful plants, the insects of 112 families.

Injurious as parasitic upon warm-blooded animals, the insects of 1 family.

Beneficial as preying upon other insects, the insects of 79 families.

Beneficial as scavengers, the insects of 32 families.

Beneficial as pollenizers only, the insects of 2 families.

Beneficial as forming food for food fishes, the insects of 3 families.

Of undetermined economic importance, the insects of 49 families.

Families containing both injurious aud beneficial forms, 22 .

The totals are:

Beneficial, the insects of 113 families.

Injurious, the insects of 116 families.

Both, or undetermined, the insects of 71 families.

CONCLUSION.

And now the question is: Are we any nearer the answer of the query in the title of this paper than we were at the start? We have, perhaps, gained by this summary a clearer idea of the economic importance of the class Insecta, and possibly it may appear by this contrasting method that the benefits derived from insects entirely offset their injuries; but we cannot, in our present stage of enlightenment (and I say it with all reverence), complacently and piously adopt, with the good old rector of Barham, the view that insects, with all the lower animals, were created for man's benefit, God permitting occasional injuries, to use Kirby's words, "not merely with punitive views, but also to show us what mighty effects he can produce by instruments so insignificant, 
thus calling on us to glorify his power, wisdom and goodness."

Contrast with this view the view of Professor Bailey, in one of his charming essays in the volume entitled "The Survival of the Unlike:" "We are now prepared to admit that this whole question of enemy and friend is a relative one, and does not depend upon right and wrong, but simply upon our own relationships to the given animals and plants. An insect which eats our potatoes is an enemy because we want the potatoes too; the insect has as much right to the potatoes as we have. He is pressed by the common necessity of maintaining himself, and there is every evidence that the potato was made as much for the insect as for the human kind. Dame Nature is quite as much interested in the insect as in man. 'What a pretty bug!' she exclaims; 'send him over to Smith's potato patch.' But a bug which eats this insect is beneficial; that is, he is beneficial to man, not to the insect. Thus everything in nature is a benefit to something and an injury to something; and every time that conditions of life are modified the relationships readjust themselves."

In these words Bailey, with his accustomed felicity, has expressed the situation admirably. Man is but one of the forms of life struggling for existence, at continual warfare with surrounding forms; but by virtue of his surpassing intelligence-itself as gradually evolved as have been the physical characteristics of any given species-he has overun the earth, has accommodated himself to the most unnatural enviromments; he has dominated all other species in nuture; he has turned to his own uses and encouraged or hastened the evolution of 
species useful to him or of useful qualities in such species; he has wiped out of existence certain inimical forms, and is gaining the control of others. He is the dominant type, and types whose existence and methods of life are opposed to his interests are being pushed to the wall. It is the culmination of a history which has many times repeated itself in past ages. The struggle of other forms of life to accommodate themselves to the conditions brought about by the rapid development of this dominant type is one the most interesting fields of study open to the biologist to-day. It would seem as if, in man's efforts to make the face of the earth his own, all the complicated elements of life were arrayed against him, and the great and ultimate result of the labor of the biologist in his study of the relations of the different forms of life and the laws which govern their development will be to bring about the absolute control of all other life by man. Thus it is not only the economic worker who looks for immediate results of a practical kind from his labor-the seientific agriculturist, the horticulturist, the economic zoologist, the medical bacteriologist - who should command the respect of even the practical-minded man, but the biologist in whatever field, however restricted it may be, whether he is working towards the understanding of broad principles and general laws, or whether in some narrow corner of research, he is accumulating material which will help ultimately to lead to wider understandings - ali are working helpfully and practically towards the perfect wellbeing of the human race.

WASHINGTON, D. C.

L. O. Howard. 


